\title{
Ecological Concept in Environmental Art Design
}

\author{
He Jiye \\ Guangdong University of Science \& Technology, Guangdong Dongguan, 523083
}

Keywords: environmental art design; ecological concept; realization way

\begin{abstract}
With the continuous development of our country's economy, people have been constantly improving standard of living, higher pursuit of spiritual life, and further elevate requirements of environmental art design, having attached importance to the protection of the ecological environment and recognized the advantages of the ecological concept. The ecological concept in the environmental art design plays a very important role to effectively solve some problems existing in the ecological environment, having a great significance for the development and protection of the environment.
\end{abstract}

\section{Introduction}

The rapid development of economy, to a certain extent, affects the ecological environment, mainly in the pursuit of economic benefits, but ignoring the protection of the ecological environment in the process of economic development. In some construction projects, the phenomenon of irrational utilization and unreasonable exploitation frequently occurs, which has caused serious damage to the ecological environment and a series of environmental problems, such as the air pollution caused by the exhaust gas emitted from the production in factories, noise pollution brought by house decoration and vehicle siren, waste pollution due to the lack of effective disposal of some garbage in life, and different levels of pollution of water quality and urban landscape led by a series of external factors, etc. These pollutions, seriously destroying the ecological balance and having a very bad impact on people's living environment, whose main reason is human factors.

\section{Environmental Art Design}

Environmental art design, including the basic concepts in design, art and environment, not only accurately determines the functions of these three aspects, but also links them together closely, having been an important means to improve and protect the ecological environment. In environmental art design, the basic knowledge mainly includes color constitution, structure physics, three-dimensional constitution, painting and architectural drawing, etc., the design theories are chiefly composed of famous culture, aesthetics, social laws and regulations, sociology, philosophy, art, economics, etc., the applied disciplines comprises botany, geology, urban planning, ecological science, architecture, electrical engineering, climatology, acoustics, materials, etc., and study areas are made up of the garden design, the landscape art, the architectural design, the city planning, the square design, the interior design, etc.

\section{The Basic Principles of Ecological Concept in Environmental Art Design}

Environmental art design must refer to the current science and technology, to make full use of advanced technology, so as to improve the use of design resources to avoid waste, thus to meet the basic needs of environmental development, and create a high-quality ecological environment. Designers should keep pace with the times, making full use of the most advanced design means, and taking the ecological concept as the premise of the design, so as to make better design with high efficiency.

In the design, we must follow the laws of the development of the nature, otherwise we will be 
punished and pay for the price. Specifically, it is necessary to respect the laws of self-renewal and evolution of the nature, make full use of its self-regulation in the design, and prevent the selection of materials beyond the natural acceptable range and recovery capability. We must clear our position, not on the opposite side of the nature.

The minimum intervention principle is to decrease the external intervention as far as possible, so as to show the effects of the environmental design. The design is carried out on a certain site, which means that it will inevitably lead to the destruction of resources and sites. Therefore, we must pay attention to control the scope of the construction site during the process of design in order to prevent unnecessary site damage. In addition, the original balance of the ecosystem should be focused on not to be destroyed in the construction, so as to facilitate the rapid stability of the post-work environment. Design materials that can be recycled and various materials should be chose, to restore the authenticity and nature of the design works.

\section{Application of Ecological Concept in Environmental Art Design}

Ecological design in essence is the use of ecological principles to guide the design of environmental art, whose main purpose is to effectively maintain the balance and the diversity of species in the natural ecosystem, and to ensure that resources in the natural ecosystem are inexhaustible. With the development of ecological environment in China, people's ecological awareness has been further strengthened, and some technologies in the natural environment have been effectively improved. The concept of ecological design is becoming more and more important in the protection of the natural environment, and gradually permeates into people's lives. The theoretical knowledge and design means of ecological design are also constantly improving and developing. The application of ecological concept in environmental art design has effectively reduced the interference of human factors in the natural environment and minimized the impact of external factors on the natural environment, promoting the balance in the natural ecosystem.

The natural ecosystem, with a very powerful self-recovery function, can self-regulate some of the damage, after which the recovery speed is very fast. However, at present, the destruction of ecological environment is not only caused by natural factors, but also man-made factors which occupy a dominant position in the destruction of the natural environment. Some garbage dumps, abandoned foundations and areas severely damaged due to human factors have become the main design objects for designers in environmental art design. Taking advantage of ecological ways to solve the environmental problems in these design objects has become the main task and goal for the environment art designers. The first thing to be considered in the design of a site that has been severely damaged is how to use ecological means to restore the environment in the site with a full account of the protection of the ecological environment so as to perfect the shortcomings and defects in the ecological environment system through environmental art design.

With the rapid development of industry in our country, a large number of ecological environment resources, especially non-renewable resources, have been consumed, resulting in the gradual reduction of ecological environment resources. So, the compensation in the environmental art design enables that the scientific and reasonable method is used to promote the self-restoration of ecological environment and to reduce the consumption of natural resources because of the development of industrialization. The application of ecological concept in environmental art design effectively reduces the consumption of non-renewable energy and improves the utilization of renewable energy such as water, wind and solar energy to a large extent.

Modern environmental art design must always adhere to the concept of recycling ecological resources, to maximize the development of renewable resources, and then to take effective use of these renewable resources and give full play to the role of ecological resources. Environmental art and design must pay attention to the utilization of natural resources, such as the combustion of fossil fuels, which produces large amounts of sulfide and nitrogen, which spread in the atmosphere to form acid rain to seriously damage the ecological environment. Therefore, strict control of fossil fuel combustion plays a very important role for the protection of the natural ecological environment and the reduction of the environmental pollution. The efficient use of solar, water and wind energy 
is of great significance for the protection of the environment and the promotion of economic development, such as solar water heaters, hydropower and wind power generation.

\section{The Concrete Way for Realization of Ecological Idea in Environmental Art Design}

Environmental art design follows the basic ecological concept to use natural environmental protection materials which have the advantages of zero pollution and high performance. as essential key materials in environmental art design and ecological concept. Therefore, environmental art designers should choose the appropriate materials, environmental protection materials to the greatest extent in the use of related material. At the same time, when using the environmental protection materials, a reasonable plan for the use of materials should be given according to the characteristics and advantages of the materials combined with the actual situation. For example, in the architectural art design, cobblestone can be choosing as the building foundation material, which can usually obtain a better ecological effect.

At present, due to the continuous expansion of the housing building scale, more and more elements affect the outdoor environmental art design in the modernization construction of housing, which leads to the construction of some outdoor landscape which is very costly and especially occupies space so that the outdoor ecological environment has been adversely affected. Therefore, reasonable planning of landscape forms, reducing landscape costs as much as possible, making outdoor landscape more practical are the requirements for outdoor environmental art design, which will enable people to enjoy comfortable and pleasant outdoor landscape.

Making good use of every inch of land is a requirement for outdoor design. A good urban environment cannot be built without green space which is the link between city people and nature, not only giving them access to nature, but also regulating the environment, the climate, and the ecological environment. Therefore, for the designers of urban planning and construction, they should effectively utilize every inch of excess space in the city, to build green space, and create a more comfortable and pleasant urban environment. In the actual work of landscape space design, more rockeries, and artificial lakes should be designed to highlight the perfect combination of modern design and nature, giving more opportunities for urban people to integrate into nature.

Our design is not to transform but to utilize the nature. Designers should fully consider the natural characteristics of habitatant and regional environment, grasp the existing natural conditions, and reduce the large scale of engineering transformation when carrying out modern outdoor environmental art design. Vegetation, topography, soil, water and other natural conditions existing in the construction base should not be changed if the local microclimate and biological chain are desired to be kept to maintain the stability of the ecological environment. Therefore, we should follow the ecological civilization in the work to build appropriate amount of artificial landscape according to the local natural conditions without destroying the local original natural landscape to the best.

People's requirements for life are constantly improving, so that they have higher requirements and ideas on whether the environment is comfortable and pleasant for the environment design. Hence, in order to meet the spiritual and material needs of people, environmental art design should put people's needs in the first place, to lead the design much closer to the users. For example, the ecological environment and buildings are combined to create a picture of man and architecture living in harmony with nature.

Need to apply the concept of ecological design to the design of environmental art, redering environmental design to be more ecological. Environmental art design must take into account the surrounding original ecological environment, and cannot destroy the original biosphere composed of animals and plants. For example, in a city full of high-rise buildings, in order to make the urban environment much closer to the nature, the proper construction of urban green belt is a good way. In the design, if more green energy is considered into and some polluting energy is limited, resources saving and ecological environment protection can be realized at the same time. For example, the Water Cube is designed to make good use of solar energy, saving a lot of energy. 


\section{Conclusion}

In the short decades of its development, modern fiber art has been based on the basic expression forms of the traditional fiber art and benefited from the ever-changing trend of artistic thoughts, with diverse themes, multi-dimensional forms, and comprehensive expression, full of personality of the main body and common experience of public art space. From the attachment to the occupation of the architectural space, it reflects the independence and expansion of an new art category, and it is also a process for a research of an art form by the artists.

\section{References}

[1] Li Weiguang. Ecological Principles in Environmental Art Design[J]. Modern Decoration Theory, 2013(06):140-141.

[2] Du Yi. Environmental Art Design-the Basic Ideas of Environmental Art Design System[J]. Art \& Design, 2015, 151(11):10-11.

[3] Wang Yang, and Shan Yidan. Discussion on Ecological Concept in Environmental Art Design[J]. MING Attitude, 2017(11):56-56.

[4] Wang Huailiang. Prospect of Environmental Art Design from Ecological Perspective[J]. Contemporary Art, 2014(1):41-43. 